ceeding thither he obtained at Constantinople the Turkish certificate, enabling him to practise medicine throughout the I'urkish empire. In 1904, after a year's residence at Nablus, he moved to Mosul in Mesopotamia, where for four years he lived a life of noble self-sacrifice and devotion to the needs of those about him. He founded a hospital, where, in the absence of the aid of any European doctor or nurse, and assisted only by native men whom he himself had trained, he performed an extensive amount of surgical work, including many majoræoperations and numerous operations for cataract and lithotomies. His collection of calculi is in the museum at Cambridge. But his unfailing obedience to the ceaseless calls on his time and strength proved too great a strain on his health, and, to. his.deep disappointment, he had to submit in 1908 to being invalided home.

It was in October, 1910, after a period of further study, during which he obtained the Cambridge D.P.H., that Griffith was appointed Superintendent and Medical Officer of Lingfield Colony for Epileptics - one of the several homes established by the National Union for Christian Social Service, and an institution the deservedly high reputation of which he has done so much to enhance. If his impaired health compelled him to confine his energies within a comparatively restricted sphere, he none the less threw them heartily into his new work, and he was able to bring to it a rare union of qualities best suited for the successful handling and treatment in colony life of a malady and temperament admittedly presenting peculiar difficulties. Himself of athletic instincts - he was an Edinburgh "blue" in football, and when abroad never so happy as in the saddle-he saw to it that his patients as far as possible lived an open-air life, abundantly supplied with occupation, recreation, and hobbies. Nevertheless, he was an omnivorous reader, and kept himself well abreast with the results of medical research, especially those which he could use to his patients' advantage. His own powers of observation and research are displayed in the contributions he made to medical and other literature, among which mention may be made of "Hereditary Factors in Epilepsy" (Review of Neurology and Psychiatry, 1911), "Cerebellar Abscess" (Scottish Medical and Surgical Fournal, 1904), "Lingfield Epireptic Colony" (The Child, 191 I), "Mental Tests in Defective Children" (The Child, 1916), "The Epileptic" (a chapter in Kelynack's Human Derelicts), and some chapters on medical missions in his wife's book, Behind the Veil in Persia and Turkish Arabia.

On intimation being made that the Ministry of Pensions were in pressing need of further accommodation for the institutional treatment and training of discharged sailors and soldiers suffering from epilepsy, and that through the British Red Cross Society initial funds would be available to meet capital expenditure, Griffith, with the assent and co-operation of his Committee and despite his precarious health, readily agreed to meet these needs so far as the possibilities at Lingfield permitted. Experience has shown that the satisfactory treatment of these particular cases is a specially difficult problem : so many of the men fail to realise their disability, and are, not unnaturally, impatient of the necessarily prolonged treatment. But Griffith knew his men; he possessed the technical skill requisite to obtain insight into their individual peculiarities and often into the origin of the latter, and his sympathy with them and determination to restore them to a normal civilian life engendered, besides affection, a loyalty to régime that explains much of his success. He had many projects in view for the development of the Lingfield Colony's sphere of usefulness, and the carrying of these into effect will be the best tribute to his memory.

Besides his patients, staff, and many friends, he leaves to mourn his loss his widow and a young daughter, the former of whom has been his indefatigable com. panion and collaborator, and to whom, throughout the ten painful weeks of his fatal illness, he made no murmur of complaint. He was buried in Lingfield Churchyard.

C. H. B.

\title{
Capt. Ernest Fryer Ballard, R.A.M.C.
}

IT is with very deep regret that we have to record the death of Capt. Ernest Fryer Ballard, R.A.M.C., at the early age of thirty-three, from influenza and pneumonia, which took place at Brighton on October 23rd last. 
Capt. Ballard received his education at the Merchant Tailors' School and at St. Thomas's Hospital, where he won a scholarship. After graduating M.B., B.S., at London University, he for upwards of four years was Assistant Medical Officer at the Somerset and Bath Asylum at Wells. He was never robust, and, his health breaking down, he returned to his home at Brighton, where for some time he was House-Surgeon to the Throat and Ear Hospital. He joined the Army in June, 1915, and, being in a very low category, he was given home service, and was attached to the and Eastern General Hospital. The experience he had gained in mental disease led to his being posted to the Portland Road Section of the and Eastern, which was devoted to the care and treatment of soldiers suffering from nervous and incipient mental conditions. He was deeply attached to the mental aspect of the work, and although he had ceased to be actively connected with this sphere of medicine for some time previous to entering the Army, he yet continued to interest himself in modern psychiatry, and particularly in psycho-analysis. He retained his membership of the Association and attended the meetings when opportunity offered. He contributed articles to the Journal-in fact his last article appeared in the October issue-and he published an Epitome of Mental Disorders, which is a useful introduction for students. He had a most agreeable personality, was an indefatigable worker, and did not spare himself in the interests of his patients.

The funeral took place at Brighton, the special service held in the Chapel of the 2nd Eastern General Hospital being attended by a large number of senior otficers and staff and also patients.

By the death of Capt. Ballard the Association has lost a very charming and accomplished member, and we tender to his family an expression of our sympathy and regret.

Capt. Ballard was passionately fond of cricket and football, but his indifferent health prevented him taking as active a part in these games as he wished. He was a keen botanist and entomologist, but his chief interest lay in his home life, devoting himself to the happiness of his parents. His brain was ever at workalways reading to acquire knowledge. Although not making much outward show, he was deeply religious, and took great pleasure in reconciling his scientific knowledge with the truths taught in Scripture.

Thomas Herbert, M.R.C.S., L.R.C.P.Lond.

WE regret to hear of the death on October 23rd, 1918, of Dr. Thomas Herbert, late Senior Assistant Medical Officer in York City Asylum, Fulford. Dr. Hopkins, Medical Superintendent of this Asylum, writes of Dr. Herbert as follows :

"Dr. Herbert had been the Assistant Medical Officer at this Asylum since its opening in March, 1906-a period of $12 \$$ years. He left here on holiday on October 18 th, and whilst on a visit to his brother-in-law in Cardiff was found dead in bed on the morning of October 23rd. The cause of death was given as valvular disease of the heart. He had not been well previous to being here, but I did not know of the existence of any heart disease, so that his death was entirely unexpected.

"I can say that he was greatly respected by the staff and patients, by whom his loss was much felt, as well as by myself, to whom he was a great assistance and an agreeable colleague."

\section{NOTICES BY REGISTRAR.}

Nursing Examinations.

Preliminary . . . . Monday, May 5th, 1919.

Final . . . . . Monday, May 12th, 1919.

Papers for Bronze Medal must reach Registrar prior to June 2oth.

The Examinations for Certificate in Psychological Medicine and Gaskell Prize will be held early in July.

For particulars apply to Registrar, Dr. A. Miller, Hatton, Warwick.

Publication of results of November Examinations has to be deferred until our April issue. 